\title{
ENVIRONMENTAL AWARENESS, ENGAGED CONSUMPTION AND ORGANIC PRODUCTS CONSUMPTION
}

CONSCIÊNCIA AMBIENTAL, CONSUMO ENGAJADO E CONSUMO DE PRODUTOS ORGÂNICOS

Recebido em 15.04.2020 Aprovado em 02.06.2020

Avaliado pelo sistema double blind review

DOI: https://doi.org/10.12712/rpca.v14i2.42212

\author{
Nágela Bianca do Prado \\ nagelabianca.prado@gmail.com \\ Programa de Pós-Graduação em Administração (FCA/UNICAMP) /Universidade Estadual de Campinas \\ (UNICAMP) - Campinas/São Paulo, Brasil \\ https://orcid.org/0000-0002-8252-7329
}

\section{Gustavo Hermínio Salati Marcondes de Moraes}

salati@unicamp.br

Programa de Pós-Graduação em Administração (FCA/UNICAMP) /Universidade Estadual de Campinas (UNICAMP) - Campinas/São Paulo, Brasil

https://orcid.org/0000-0001-5238-0314

\begin{abstract}
The objective of this study was to evaluate how some environmental awareness dimensions influence consumer engagement and, consequently, the intention of consuming organic products. The methodology used was quantitative and the data were analyzed by structural equation modeling. The results obtained from a sample made up of 213 university students confirmed three hypotheses raised for research: the precautions taken in the domestic environment and mobilizing attitudes towards environmental positively influence more engaged consumption, and an engaged consumer has a greater intention of consuming organic products. Thus, the present study provides relevant information on the behavior of individuals in this market.
\end{abstract}

Keywords: Environmental awareness. Consumer engagement. Consumption of organic products. Buying behavior.

\section{Resumo}

O objetivo deste estudo foi avaliar como dimensões da consciência ambiental influenciam o engajamento do consumidor e a intenção de consumo de produtos orgânicos. A metodologia utilizada foi quantitativa e os dados foram analisados por modelagem de equações estruturais. Os resultados obtidos a partir de uma amostra composta por 213 estudantes universitários confirmaram três hipóteses: precauções tomadas no ambiente doméstico e atitudes mobilizadoras frente as questões ambientais influenciam positivamente um consumo mais engajado, e um consumidor engajado tem uma maior intenção de consumo de produtos orgânicos. Desta forma, o estudo fornece informações relevantes sobre o comportamento dos indivíduos nesse mercado.

Palavras-chave: Consciência ambiental. Envolvimento do consumidor. Consumo de produtos orgânicos. Comportamento de compra. 


\section{Introduction}

In recent years, the market for natural and organic products has presented an accelerated growth, demonstrating a worldwide trend of increasing demand with offers in various segments (Gonçalves-Dias, Teodósio, Carvalho, \& Silva 2009; Green America, 2013; Toni, Eberle, Larentis, \& Milan, 2018). This growth is due to a change in the consumers behavior, who now have a greater perception and concern regarding environmental issues and personal well-being, thus opting for new consumption trends, the so-called aware consumption, which also manifests through the organic products consumption practice, whose production process does not harm the environment (Portilho, 2008). Although organic products are not the only category in sustainable consumption, its consumption is perceived as an opportunity to increase the pro-environmental aspects in food consumption (Mondini, Borges, Mondini, \& Dreher, 2018).

The adoption of an aware behavior demands a learning process (Jacomossi, Morano, \& Barrichello, 2014). Understanding and developing this environmental awareness in university students is extremely relevant so that they are able to, when entering the labor market, influence the decisions that involve the adoption of environmental issues within corporations. Moreover, expanding the environmental vision under the corporate view, it is assumed that the buying behavior of the student, as an individual, has a greater propensity to awareness (Gonçalves-Dias et al., 2009).

Environmental awareness has been the focus of research that sought to create indicators for its measurement (Pato, 2004; Straughan \& Roberts, 1999), and some aspects are recurrent in the instruments presented, such as: aware consumption of products and services of companies; healthy food; waste disposal within the home and in public areas; electric energy saving; water saving; reuse of products; reaction to environmentally incorrect postures from other people; and participation in environmental protection initiatives. These aspects can be grouped into environmental awareness dimensions (Gonçalves-Dias et al., 2009), as follows: engaged consumption; concern with waste; mobilization; and domestic environment.

This research aimed to propose and test a theoretical model to evaluate how some dimensions of environmental awareness influence consumer engagement and how this engagement influences the intention of consuming organic products. Therefore, the research questions are: "What is the influence of concern with waste, mobilization, and domestic environment on engaged consumption?" and "What is the influence of engaged consumption on the intention of consuming organic products?".

The increased citizens environmental awareness can lead to a higher organic products consumption (Sarkis, Zhu, \& Lai, 2011), and studies on the relations between the environmental and social dimensions and the motivations for organic food consumption still needed to be better explored (Dias, Schultz, Schuster, Talamini, \& Révillion et al., 2015; Toni et al., 2018).

The paper is structured in four parts, in addition to this introduction. In section 2, we begin to present the theoretical framework approaching the dimensions of environmental awareness and consumption of organic products. Section 3 describes the methodological part of the study. The results are presented in section 4 and discussed in the light of the literature on section 5. Finally, we present the study's final considerations, indicating its contributions, limitations, and suggestions for future studies.

\section{Theoretical Framework}

The theoretical framework presents the literary foundations needed to support this research, in addition to the formulation of study hypotheses.

\section{Environmental awareness dimensions}


The act of consuming is intrinsic to the human being and, therefore, there are few reflections regarding how consumption signs directly impact quality of life. According to Pinto and Batinga (2016, p. 31), "consumption is a complex field of research, which encompasses various activities, actors, and a set of goods and services that are not necessarily limited to those provided in the form of products". Thus, the consumer is the person who performs acts of consumption, or rather, the one who appropriates and makes use of products (Bauman, 2008).

Consumption has a double function: to produce identity, through its signs, and also to satisfy needs and wants. It also reflects cultural aspects, possessing meanings that are shared within societies and times, thus allowing the distinction of social strata, in addition to be considered ambiguous by, in parallel, being synonymous with use as well as with depletion (Pinto \& Batinga, 2016). Consumer evolution is constant and cultural factors influence changes in consumption habits, such as the capitalist system that preaches that the human being can reflect who he/she is through his/her purchases (Bauman, 2008; Sousa \& Romero, 2018; Yin, Yang, Zhang, Zhang, Cai, Hao, Cui, \& Chen, 2020).

Regarding environmental issues, as a reflection of the social inequalities subsidized by consumerism, it is possible to observe the irregularity in access to water in several regions of the planet, as well as the large urban centers pollution, global warming, deforestation, erosion, economic and cultural poverty, and insufficient natural resources necessary for the maintenance of living beings (Lima, Ferreira, Bezerra, Feitosa, \& Gómez, 2016; Rotta, Batistela, \& Ferreira, 2017; Telocken, Garlet, Favarin, Madruga, \& Trevisan, 2017).

In an attempt to mitigate the harmful impacts caused by the compulsory act of consumption, there was an increase related to the ethical concern regarding the industrial conduct to the environment also by the consumer market, which began to observe the production chain of their acquisitions. This new perception and appreciation about environmental issues stimulated the emergence of a series of strategies, such as green consumption, ethical consumption, responsible consumption, and aware consumption, in addition to the manifestation of a new environmental policy proposal known as sustainable consumption, which have broadened the discussions in the media, as well as in the business and academic contexts, for assigning new characteristics and concepts to consumption, regarding concerns with environmental, social, and ethical aspects involved in the purchase act (Pinto \& Batinga, 2016).

Aware consumption, therefore, encompasses the result of human reflection, concerning the individual consumption impacts on the environment, seeking the improvement and collective life maintenance (Lima et al., 2016; Mondini et al. 2018; Pinto \& Batinga, 2016) aimed at only buying goods strictly necessary to prevent the generation of waste, coming from companies that adopt an environmentally ethical posture.

In Brazil, the term aware consumption began to be taken seriously from the 1980s, however, there are records of claims between the 1930s and 1950s, organized in the country by consumers against the lack of products and the high prices (Minehira, 2010).

Aware consumption, in its turn, does not aim to contain, but rather to guide development towards the preservation of the environment and non-renewable resources (Macêdo \& Oliveira, 2005; Sousa \& Romero, 2018). In this context, when adhering to environmental awareness, the individuals renounce their selfish consumption practices aimed at immediate satisfaction to establish a bond with society and prioritize the collective good (Chiaretti \& Sarti, 2017). Therefore, aware consumption is a lifestyle that needs to be created to support environmental protection values through practices of recycling, reuse, and reduction, being the main element to demand the offering of sustainable products by the market (Lima et al., 2016; Pinto \& Batinga, 2016). 
Aware consumption practices can be expressed in several dimensions, which may even impact on the realization of green products purchases. In the domestic environment, for example, concerns about saving water and energy and recycling waste represent aware attitudes (Aprile \& Fiorillo, 2019). These concerns, in the study by Pato, Ros, and Tamayo (2005), are enough for a behavior to be considered ecological, currently. In the study, carried out with Brazilian university students, only four antecedents characterized the ecological behavior of participants: activism, water and energy savings, urban cleaning, and recycling (Pato, Ros, \& Tamayo, 2005).

Mondini et al. (2018) affirm that conscious consumers take more responsibility in their purchase choices, avoiding waste and influencing other people to consume in a more conscious way, that is, they mobilize in face of environmental issues and fight for the environment preservation (Aprile \& Fiorillo, 2019). The authors even carried out a survey, in which they interviewed 182 Brazilian university students, and concluded that the intention to buy ecological products is greater when the consumer is more aware of environmental issues.

Regarding the domestic environment, Barbosa \& Veloso (2014) consider that the daily domestic practices reflect the individual's awareness degree, especially in the food, personal hygiene and cleaning activities, such as the simultaneous use of various household appliances and electronics that demand the electricity use, food waste, e water excessive use in cleaning, bathing, washing clothes and dishes, incorrect disposal of garbage etc.

The research considered these dimensions to formulate the first three study hypotheses:

H1: The precautions taken in the domestic environment positively influence a more engaged consumption.

H2: The mobilizing attitude towards the environment positively influences a more engaged consumption.

H3: Concerns about waste positively influence more engaged consumption.

As a result, the topic of organic product consumption is presented along with the development of the fourth research hypothesis.

\section{Organic products consumption}

Organic agriculture has emerged as an alternative to mitigate the impacts generated from the green revolution, which deployed, at the end of the 1940s, techniques for promoting greater productivity, encompassing the mechanization in the field, agrochemicals use, deployment of transgenic seeds, and artificial fertilization of the soil (Campos, Hidalgo, Kist, Pedroso, \& Dalmoro, 2018; Pinheiro, Carneiro, Pinheiro, \& Nascimento, 2018).

Thus, organic production is based on the use of fertilizers that are not environment hazard, based in sustainable principles, targeting a production process that is environmentally friendly, socially just, and economically viable, generating benefits to human beings and the environment, using the technology in favor of a sustainable production in the economic and environmental perspectives (Ormond, Paula, Faveret Filho, \& Rocha, 2002; Hoppe, Barcellos, Vieira, \& Matos, 2012; Hoffmann \& Schlicht, 2013; Pinheiro et al., 2018).

As consequence, organic products represent both food and environmental security, as they aid the health of the ecosystem and of living beings, combining innovation and science for the promotion of responsibility to future generations (IFOAM, 2014; Pinheiro et al., 2018). Therefore, choosing organic products is synonymous with a consumption choice of supporting life, whose purchasing process begins before the acquisition of the product and ends after its consumption, with the correct disposal concern (Kim, 2018). 
Currently, the most varied categories of products originating from an organic production system are gradually more common, since this market (which is still in formation) is favored and is shaped by the tendency, even, of searching for fitness and a healthier lifestyle, as there is scientific evidence that ensures the correlation between health and diet (Dalmoro, 2018; Hoppe et al., 2012; Hsu, Chang, \& Lin, 2018; Kim, 2018; Lombardi, Moori, \& Sato, 2005; Rodrigues, Carlos, Mendonça, \& Correa, 2009).

Consequently, organic production has an increased boost from a consuming class that seeks healthier foods, whose form of production does not impact the environment and characterizes a sustainable development model and favoring the collectivity (Hoppe et al., 2012; Pinheiro et al., 2018; Yin et al., 2020).

In Brazil, the search for sustainable food increased from the economic growth, through the possibility of citizens seeking to satisfy wishes that go beyond the basic needs. In this context, the companies also found a possibility of market expansion through the sale of products with environmental appeal (Barcellos, Bossle, Perin, \& Vieira, 2015). From this scenario, it is possible to deduce that the beginnings of consumption of environmentally friendly products represent purchasing power and favorable economic condition.

Representing psychological, cultural, political, religious, ecological, and social signs, establishments that sell products from organic and/or natural production have to be cautious about their brand positioning concerning social responsibility (Barcellos et al., 2015; Campos et al., 2018; Dalmoro, 2018; Lombardi, Moori, \& Sato, 2005). This is because the consumer is attracted to buy from a set of factors including price, location, appearance, and product quality, which arise from the replacement of the use of agrochemicals that contaminate nature.

However, products originated from an organic production system still represent a small portion in the retail consumer market (Lombardi, Moori, \& Sato, 2005). It happens since the consumer class that understands that the consumption, mainly of foods from organic farming, is a reliable investment that ensures health and quality of life, instead of the damage which the adverse effects of the use of conventional agriculture cause human health is still small (Hoffmann \& Schlicht, 2013; Hsu, Chang, \& Lin, 2018; Lombardi, Moori, \& Sato, 2005; Pinheiro et al., 2018; Sousa \& Romero, 2018).

Hsu, Chang and Lin (2018) advocate that companies have adopted slogans and management practices that are consistent with the pursuit of the consumer market for organic products in search of food security, especially, given that this concept gained momentum with the credibility crisis of the food production and industrialization sector due to the contamination of foods (Burnier, Guerra, \& Spers, 2018).

It is assumed that "intention" is a mediator between attitude and behavior, that is, it motivates the consumption practice (Sousa \& Romero, 2018). In a competitive scenario, companies develop several alternatives to attract customers and, consequently, the purchase intention is affected by several variables. However, when it comes to the intention to consume organic products, it is based on the premise that the consumer is willing to include the ecological variable in his/her purchases and has a greater direction of what he seeks, not allowing himself to be taken to factors such as price and convenience, but valuing quality (Sousa \& Romero, 2018).

The research conducted by Sousa \& Romero (2018) investigated 308 Brazilian university students in the engineering area in order to understand the material value attributes influence on the intention to buy ecological products, in addition to analyzing the ecological values consumption influence on the purchase intention. The authors found that there is a positive influence between the ecological products valuation on the intention to purchase ecological products. 
In this context, it is expected, therefore, that aware consumers know how to distinguish environmentally friendly foods, as in the case of organic products, from conventional farming techniques (Barcellos et al., 2015; Sousa \& Romero, 2018). In this context, the fourth study hypothesis emerges:

\section{H4: An engaged consumer has greater intention of consuming organic products.}

Hereafter, we present the methodological aspects used as an aid to achieve the objective of this study.

\section{Methodological Aspects}

The research was developed through a quantitative methodology, using multivariate data analysis. Since the research goals are the prediction and explanation of the constructs engaged consumption and intention of consuming organic products and the model has not yet been validated in the literature, we opted for the use of the Partial Least Squares Structural Equation Modeling (PLS-SEM) (Hair et al., 2017). The structural equation modeling use was chosen, since it is a statistical technique considered from second generation, often used in the causal analysis context between measurable quantities and latent constructs (Hair et al., 2018). A single cross-section was performed and the data were collected through a questionnaire with Likert format scales with seven points. The research was conducted in a nonprobabilistic way and with a convenience sample, through personal interview with 213 university students.

The G* Power software 3.1.5 (Faul, Erdfelder, Buchner, \& Lang, 2009) was used to evaluate the sample size and statistical power of the analyses, according to the recommendations by Chin and Newsted (1999) and Hair et al. (2017). The largest number of arrows that come to a latent variable is 3 (highest number of predictors). Considering 3 predictors, a significance level of $5 \%$, statistical power of 0.8 , and average effect size ( $\mathrm{f}^{2}=0.15$, which is equivalent to $\mathrm{r}^{2}=13 \%$ ), the minimum size of the sample is 77 . As the sample used was of 213 respondents, it is suitable for estimates by PLS-SEM. The post hoc analyses for the sample obtained indicate that: a) any $\mathrm{r}^{2}$ higher than $4.96 \%$ would be detected as significant, keeping the power of 0.8 and the significance level at $5 \%$; b) for the average effect size, the power is of 0.998 , being higher than the value of 0.8, recommended by Chin and Newsted (1999) and Hair et al. (2017).

The Software SmartPLS 3.0 M3 (Ringle, Wende, \& Becker, 2015) was used to calculate and validate the statistical tests, developed using the technique of structural equation by multivariate analysis.

The conceptual model of the research is presented in Figure 1.

Figure 1. Conceptual model of the research

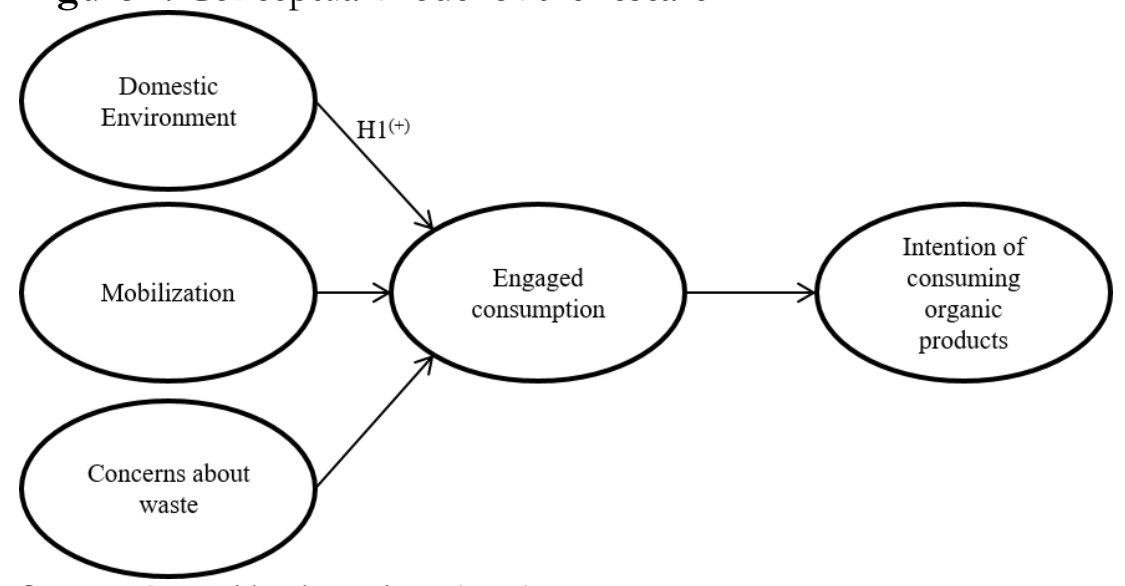

Source: Created by the authors (2019) 


\section{Results Description}

To present the description and analysis of the results, the topic is divided into three parts: confirmatory factor analysis; evaluation of the reflective measurement models; and evaluation of the structural model.

\section{Confirmatory factor analysis}

The measurement instrument was adapted from Gonçalves-Dias et al. (2009), but some questions were prepared by the authors. Thus, we opted to perform a confirmatory factor analysis (CFA) to evaluate the psychometric properties of the measures with the support of the software SmartPLS 3 (Ringle, Wende \& Becker, 2015).

CFA is a statistical technique which seeks to define, in a study with multiple variables, sets of highly correlated variables and, thus, confirm the adjustment of the observed data degree to an already existing theory. In studies involving structural equation modeling, CFA is used as an important step in verifying the structural model (Hair et al., 2017). In this way, all measures were tested on the same model and restricted to be loaded into their respective factor (Brady \& Cronin, 2001). The measures with factorial loading greater than or equal to 0.7 were kept in the model (Hair et al., 2009). However, in measures with factorial loadings greater than 0.4 and smaller than 0.7 , the impacts of their exclusion were assessed by average variance extracted (AVE) and composite reliability that are indicators associated with the measurement quality.

An AVE whose value is equal to or greater than 0.5 indicates that, on average, the construct explains more than half of the variance of its indicators. The composite reliability, in turn, considers the different external loads of the indicator variables, whose values vary between 0 and 1 . The closer to 1 , the greater the level of reliability (Hair et al., 2017). Only the measures that harmed AVE and the composite reliability were excluded from the model, as recommended by Hair et al. (2017). Thus, only the construct concern with waste had no indicator eliminated, while the other constructs had at least one indicator reduced.

The results of the CFA and the descriptive statistics of the indicators kept in the model are presented in Table 1.

Table 1. Standardized CFA path loadings and descriptive statistics

\begin{tabular}{|c|c|c|c|c|c|}
\hline Questions & $\begin{array}{l}\text { Standardized } \\
\text { path loading }\end{array}$ & $\begin{array}{c}\text { Critical } \\
\text { ratio }\end{array}$ & P-value & Mean & $\begin{array}{l}\text { Standard } \\
\text { deviation }\end{array}$ \\
\hline \multicolumn{6}{|l|}{ Domestic environment a } \\
\hline (DE1) I avoid taking time to shower & 0.672 & 10.91 & 0.000 & 0.669 & 0.062 \\
\hline (DE2) I avoid having the refrigerator open for long & 0.766 & 15.876 & 0.000 & 0.765 & 0.048 \\
\hline $\begin{array}{l}\text { (DE3) I avoid letting the lights on in environments that are not used when } \\
\text { I'm at home }\end{array}$ & 0.711 & 10.644 & 0.000 & 0.703 & 0.067 \\
\hline (DE4) I avoid leaving the tap open while I brush my teeth & 0.755 & 12.148 & 0.000 & 0.752 & 0.062 \\
\hline \multicolumn{6}{|l|}{ Engaged consumption ${ }^{a}$} \\
\hline (EC1) I have paid more for environmentally correct products & 0.682 & 15.711 & 0.000 & 0.681 & 0.043 \\
\hline (EC2) I try to buy products made from recycled material & 0.697 & 14.615 & 0.000 & 0.698 & 0.048 \\
\hline \multirow{3}{*}{$\begin{array}{l}\text { environment } \\
\text { (EC4) I try to buy products made from recycled material } \\
\text { (EC5) I have already convinced others not to buy products that harm the } \\
\text { environment }\end{array}$} & 0.778 & 23.647 & 0.000 & 0.776 & 0.033 \\
\hline & 0.612 & 11.532 & 0.000 & 0.608 & 0.053 \\
\hline & 0.783 & 31.493 & 0.000 & 0.783 & 0.025 \\
\hline \multirow{3}{*}{$\begin{array}{l}\text { (EC6) Concerns about the environment interfere with my purchase decision } \\
\text { (EC7) I read the label carefully before deciding to buy } \\
\text { (EC8) I try to reduce my consumption of scarce natural resources }\end{array}$} & 0.861 & 44.752 & 0.000 & 0.862 & 0.019 \\
\hline & 0.584 & 10.435 & 0.000 & 0.582 & 0.056 \\
\hline & 0.651 & 13.78 & 0.000 & 0.65 & 0.047 \\
\hline \multicolumn{6}{|l|}{ Mobilization $^{a}$} \\
\hline \multirow{4}{*}{$\begin{array}{l}\text { (MB1) I talk about the importance of the environment with other people } \\
\text { (MB2) I mobilize people for the conservation of scarce natural resources } \\
\text { (MB3) I have already denounced actions that were harmful to the } \\
\text { environment } \\
\text { (MB4) I catch the attention of people throwing paper on the floor }\end{array}$} & 0.871 & 48.173 & 0.000 & 0.872 & 0.018 \\
\hline & 0.878 & 43.86 & 0.000 & 0.878 & 0.020 \\
\hline & 0.643 & 12.31 & 0.000 & 0.642 & 0.052 \\
\hline & 0.578 & 7.671 & 0.000 & 0.576 & 0.075 \\
\hline
\end{tabular}

Concerns about waste ${ }^{a}$ 
(CW1) When there is no bin nearby, I keep the paper I do not want in my pocket anymore

(CW2) I avoid throwing paper on the floor

(CW3) I help keep the streets clean

(CW4) I do not play empty beer cans or soda on the floor

Intention of consumption of organic products ${ }^{b}$

(ICOP1) Fruits, vegetables and herbs

(ICOP2) Tubers and grains

(ICOP3) Nuts and nuts

(ICOP4) Herbs, Seasonings and Teas

(ICOP5) Cereals, salts and meal

(ICOP6) Oils and vinegars

(ICOP7) Cosmetics and personal hygiene

\begin{tabular}{lcccc}
0.868 & 18.498 & 0.000 & 0.861 & 0.047 \\
0.907 & 25.851 & 0.000 & 0.901 & 0.035 \\
0.567 & 7.020 & 0.000 & 0.569 & 0.081 \\
0.686 & 6.771 & 0.000 & 0.674 & 0.101 \\
\hline 0.709 & 13.849 & 0.000 & 0.709 & 0.051 \\
0.761 & 17.362 & 0.000 & 0.755 & 0.044 \\
0.728 & 15.928 & 0.000 & 0.725 & 0.046 \\
0.814 & 28.972 & 0.000 & 0.813 & 0.028 \\
0.765 & 15.909 & 0.000 & 0.759 & 0.048 \\
0.668 & 9.442 & 0.000 & 0.659 & 0.071 \\
0.585 & 8.089 & 0.000 & 0.579 & 0.072 \\
\hline
\end{tabular}

a Likert scale responses from 1 (totally disagree) to 7 (totally agree). The students responded how much they agreed with the statements.

${ }^{\mathrm{b}}$ Likert scale responses from 1 (never) to 7 (oftentimes). The students responded regarding the probability of consuming the following categories of organic products.

Source: Created by the authors (2019)

\section{Evaluation of the reflexive measurement model}

All research model constructs are reflective, and the criteria for evaluation, according to Hair et al. (2017) are: internal consistency, reliability of the indicator, convergent validity, and discriminant validity.

Convergent validity is the extent to which a measure correlates positively with alternative measures of the same construct. This evaluation considers the external loads of the indicators and the AVE. The discriminant validity, in turn, determines that a construct is unique and captures phenomena not represented by other constructs in the model. For that, cross loads can be analyzed, in which the external load of an indicator in the associated construction must be greater than any of its cross loads in other constructions (Hair et al., 2017).

The convergent and discriminant validities were assessed at the level of the indicators and of the latent variables. In the analysis of the cross-factorial loadings, most of the indicators presented high factorial loadings in their latent variables, higher than 0.70 , and low in the remaining latent variables. However, some indicators presented values lower than 0.70 in their latent variables. According to the suggestions by Hair et al. (2017), after analyzing indicators of composite reliability and Cronbach's alpha of the constructs, it was not necessary to exclude any indicators. The exclusion tests of the indicators that remained within values from 0.40 to 0.70 did not imply improvements in the model evaluation indicators, thus, they were maintained (Hair et al., 2017). Table 2 presents the cross-factorial loadings of the measurement model.

Convergent validity was also evaluated by the value of the average variance extracted (AVE), which, as a criterion for validation, should present a value greater than 0.5 (Hair, Ringle, \& Sarstedt, 2011). Table 3 presents these values, which are adjusted.

To evaluate the measurement model, a main measure used, in addition to the examination of the loadings for each indicator, is the composite reliability of each construct (Hair et al., 2009; Hair et al., 2017). A reference value commonly used for acceptable reliability is 0.70 and the values are in accordance with the established (Table 3).

To analyze convergent validity, internal consistency was verified. A high value of internal consistency in the construct indicates that all variables represent the same latent construct. Internal consistency is evaluated by Cronbach's alpha, that measures the correlation between responses in a questionnaire by analyzing the responses given by the respondents, showing an average correlation between the questions (Hair et al., 2017), which varies from 0 to 1, with higher values indicating a high consistency level. For exploratory studies, values between 0.60 and 0.70 are considered acceptable; to studies at more advanced 
stages, values between 0.70 and 0.90 are considered satisfactory (Nunally \& Berstein, 1994; Hair et al., 2017). According to Table 3, these values are adjusted.

Table 2. Cross-factor loadings

\begin{tabular}{cccccc}
\hline Indicators & $\begin{array}{c}\text { Domestic } \\
\text { environmen } \\
\mathbf{t}\end{array}$ & $\begin{array}{c}\text { Engaged } \\
\text { consumption }\end{array}$ & $\begin{array}{c}\text { Intention of } \\
\text { consuming }\end{array}$ & Mobilization & $\begin{array}{c}\text { Concerns } \\
\text { about waste }\end{array}$ \\
\hline DE1 & $\mathbf{0 . 8 0 6}$ & 0.267 & 0.036 & 0.148 & 0.188 \\
DE2 & $\mathbf{0 . 8 0 2}$ & 0.222 & 0.091 & 0.151 & 0.270 \\
DE3 & $\mathbf{0 . 6 2 0}$ & 0.118 & 0.136 & 0.038 & 0.349 \\
DE4 & $\mathbf{0 . 6 3 9}$ & 0.147 & 0.009 & 0.177 & 0.438 \\
EC1 & 0.138 & $\mathbf{0 . 6 8 4}$ & 0.264 & 0.425 & 0.165 \\
EC2 & 0.171 & $\mathbf{0 . 6 9 9}$ & 0.227 & 0.374 & 0.145 \\
EC3 & 0.278 & $\mathbf{0 . 7 7 9}$ & 0.213 & 0.366 & 0.194 \\
EC4 & 0.169 & $\mathbf{0 . 6 1 3}$ & 0.187 & 0.250 & 0.185 \\
EC5 & 0.162 & $\mathbf{0 . 7 7 9}$ & 0.308 & 0.628 & 0.183 \\
EC6 & 0.246 & $\mathbf{0 . 8 5 8}$ & 0.217 & 0.550 & 0.225 \\
EC7 & 0.132 & $\mathbf{0 . 5 8 8}$ & 0.234 & 0.339 & 0.079 \\
EC8 & 0.284 & $\mathbf{0 . 6 5 2}$ & 0.254 & 0.449 & 0.174 \\
ICOP1 & 0.167 & 0.28 & $\mathbf{0 . 7 0 9}$ & 0.279 & 0.121 \\
ICOP2 & 0.070 & 0.152 & $\mathbf{0 . 7 4 7}$ & 0.248 & -0.009 \\
ICOP3 & -0.012 & 0.039 & $\mathbf{0 . 6 4 7}$ & 0.092 & -0.002 \\
ICOP4 & 0.058 & 0.169 & $\mathbf{0 . 5 6 5}$ & 0.212 & 0.093 \\
ICOP5 & 0.014 & 0.229 & $\mathbf{0 . 7 7 0}$ & 0.231 & 0.020 \\
ICOP6 & 0.019 & 0.281 & $\mathbf{0 . 7 4 4}$ & 0.268 & 0.042 \\
ICOP7 & 0.049 & 0.320 & $\mathbf{0 . 8 1 8}$ & 0.327 & 0.088 \\
MB1 & 0.126 & 0.558 & 0.342 & $\mathbf{0 . 8 7 1}$ & 0.236 \\
MB2 & 0.187 & 0.539 & 0.298 & $\mathbf{0 . 8 8 5}$ & 0.178 \\
MB3 & 0.157 & 0.426 & 0.205 & $\mathbf{0 . 6 6 6}$ & 0.061 \\
MB4 & 0.073 & 0.303 & 0.223 & $\mathbf{0 . 5 4}$ & 0.299 \\
CW1 & 0.368 & 0.23 & 0.005 & 0.178 & $\mathbf{0 . 8 6 1}$ \\
CW2 & 0.446 & 0.192 & 0.053 & 0.195 & $\mathbf{0 . 8 7 4}$ \\
CW3 & 0.122 & 0.157 & 0.125 & 0.246 & $\mathbf{0 . 6 1 3}$ \\
CW4 & 0.186 & 0.142 & 0.121 & 0.139 & $\mathbf{0 . 7 0 3}$ \\
\hline
\end{tabular}

Source: Created by the authors (2019)

Table 3 also presents the correlation between the latent variables and the square root of the average variance extracted, which is presented in bold on the diagonal. This value must be greater than the correlation between latent variables (Fornell \& Larcker, 1981). According to the results, no correlation value between the latent variables is higher than the values of the square root of the extracted mean variance (diagonal), thus indicating that the values are adjusted. 
Table 3. Summary of the evaluation of measurement models

\begin{tabular}{lccccc}
\hline \multicolumn{1}{c}{ Constructs } & DE & EC & IPOP & MB & CW \\
\hline Domestic environment & $\mathbf{0 . 7 2 2}$ & & & & \\
Engaged consumption & 0.278 & $\mathbf{0 . 7 1 2}$ & & & \\
Intention of consuming organic products & 0.084 & 0.338 & $\mathbf{0 . 7 1 9}$ & & \\
Mobilization & 0.185 & 0.620 & 0.359 & $\mathbf{0 . 7 5 5}$ & \\
Concerns about waste & 0.384 & 0.24 & 0.086 & 0.244 & $\mathbf{0 . 7 7 0}$ \\
\hline Cronbach's Alpha & 0.705 & 0.858 & 0.850 & 0.736 & 0.765 \\
Composite Reliability & 0.811 & 0.890 & 0.881 & 0.836 & 0.851 \\
Average Variance Extracted (AVE) & 0.522 & 0.507 & 0.517 & 0.569 & 0.594 \\
\hline
\end{tabular}

Source: Created by the authors (2019)

\section{Evaluation of the structural model}

The evaluation of the collinearity of the structural model was performed prior to the structural model analysis. Thus, VIF values were analyzed for each subpart of the structural model. The Variance Inflation Factor (VIF) measures how much of the variance of each regression coefficient in the statistical model is inflated in relation to the situation in which the independent variables are not correlated (Hair et al., 2017). Here, the values are within the established by Hair et al. (2017), being below 5 .

To analyze the significance of indicators, the bootstrapping technique was used (Efron \& Tibshirani, 1998), presenting the Student's t statistic, which examines the hypothesis that the coefficients of relationship are equal to zero. If the results of this test indicate values higher than 1.96, the hypothesis is rejected and the relationship is significant (Efron \& Tibshirani, 1998; Hair et al., 2017). In the bootstrapping procedure, subsamples are removed from the original sample with replacement in order to estimate the PLS path model (Hair et al., 2017).

Table 4 presents the structural coefficients of the measurement model and Student's t statistic. All relationships showed significant values (a significance level of 5\%), except for the relationship between concern with waste and engaged consumption

Table 4. Coefficients of the structural model - between constructs

\begin{tabular}{lcccc}
\hline \multicolumn{1}{c}{ Path } & $\begin{array}{r}\text { Sample } \\
\text { Mean }\end{array}$ & $\begin{array}{c}\text { Standard } \\
\text { Deviation }\end{array}$ & T-Statistics & P-Values \\
\hline $\begin{array}{l}\text { Domestic environment -> Engaged } \\
\text { consumption }\end{array}$ & 0.156 & 0.063 & 2.480 & 0.013 \\
$\begin{array}{l}\text { Mobilization -> Engaged consumption } \\
\begin{array}{l}\text { Concerns about waste -> Engaged } \\
\text { consumption }\end{array}\end{array}$ & 0.338 & 0.050 & 6.802 & 0.000 \\
$\begin{array}{l}\text { Engaged consuption -> Intention of } \\
\text { consuming organic products }\end{array}$ & 0.038 & 0.058 & 0.651 & 0.515 \\
\hline Source: Created by the authors $(2019)$ & 0.050 & 6.802 & 0.000 \\
\hline
\end{tabular}

Source: Created by the authors (2019)

To evaluate the coefficient of determination $\left(\mathrm{r}^{2}\right)$, we used the studies by Cohen (1988) and Faul et al. (2009), which determine that $\mathrm{f}^{2}$ values equal to $0.02,0.15$, and 0.35 are considered, respectively, as small, medium, and large effects. These $\mathrm{f}^{2}$ values represent $\mathrm{r}^{2}$ values equal to $2 \%, 13 \%$, and $25 \%$, respectively.

According to the analysis, the construct of engaged consumption presented a $\mathrm{r}^{2}$ of 0.414 , considered high, while the construct intention of consuming organic products presented a $\mathrm{r}^{2}$ of 0.115 , considered medium. 
The model resulting from the research is presented in Figure 2.

Figure 2. Model resulting from research

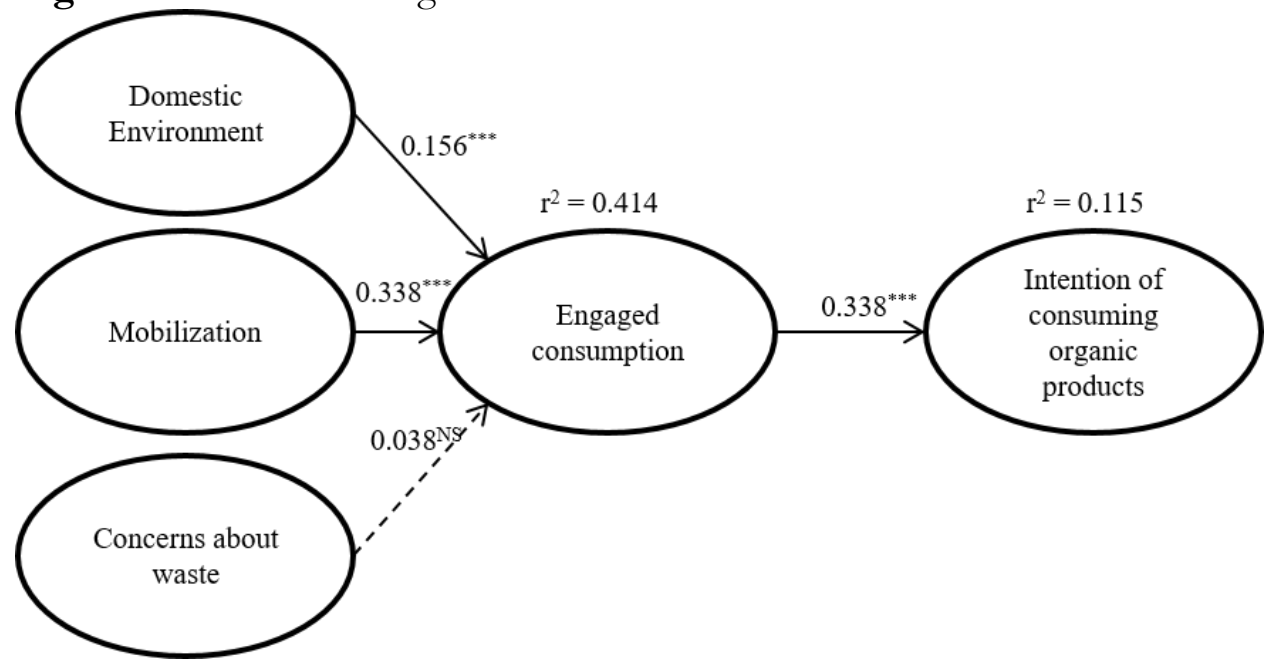

Observation $1: *=$ significant at $5 \%$; $*$ significant at $1 \%$; *** = significant at $0.1 \%$; NS $=$ not significant.

Source: Created by the authors (2019)

In addition to evaluate the magnitude of $\mathrm{r}^{2}$ values as a criterion of predictive accuracy, the $\mathrm{Q}^{2}$ value was also evaluated, which is an important indicator of the model's predictive relevance. The coefficient of determination $\left(\mathrm{r}^{2}\right)$ is a measure most used to assess the structural model, or which represents the amount of variation in endogenous constructions explained by all exogenous builders connected to it. The $r^{2}$ value ranges from 0 to 1 . A higher value indicates a higher predictive level. In contrast, the $\mathrm{Q}^{2}$ value is a measure that analyzes or can be predictive for a sample or a predictive model relevance (Hair et al., 2017). When a PLS-SEM model has predictive relevance, it predicts accurately the data points of the indicators in reflective measuring models. Table 5 presents the values of $\mathrm{r}^{2}$, adjusted $\mathrm{r}^{2}$, and $\mathrm{Q}^{2}$.

Table 5. Results of the values of $r^{2}$ and $Q^{2}$

\begin{tabular}{cccc}
\hline Construct & R Square & R Square Adjusted & $\mathbf{Q}^{\mathbf{2}}$ \\
\hline Engaged consumption & 0.414 & 0.405 & 0.186 \\
Intention of consuming organic products & 0.115 & 0.110 & 0.044 \\
\hline
\end{tabular}

Source: Created by the authors (2019)

For SEM models, $\mathrm{Q}^{2}$ values greater than zero for a specific reflective endogenous latent variable indicate the predictive relevance of the path model. In the case of this study, the value is greater than zero.

With the validations obtained with the structural model, we obtained the synthesis of the study hypothesis tests (Table 6).

Table 6. Synthesis of the study's hypothesis tests

\begin{tabular}{clc}
\hline Hypothes is & \multicolumn{1}{c}{ Description } & Res ult \\
\hline H1 & $\begin{array}{l}\text { The precautions taken in the domestic environment positively influence a more } \\
\text { engaged consumption } \\
\text { The mobilizing attitude towards the environment positively influences a more engaged } \\
\text { H2 }\end{array}$ & $\begin{array}{c}\text { Confirmed } \\
\text { Confirmed }\end{array}$ \\
H3 & $\begin{array}{l}\text { Concerns about waste positively influence more engaged consumption } \\
\text { H4 }\end{array}$ An engaged consumer has a greater intention of consuming organic products. & Not confirmed \\
\hline Source: Created by the authors (2019) & Confirmed \\
\hline
\end{tabular}




\section{Results Analysis and Discussion}

The previous session presented the data results obtained from a research carried out with university students in order to understand whether an engaged consumer, influenced by the precautions taken in domestic environment, mobilization attitude towards environmental issues and concern about waste, is more likely to consume organic products. For that, a theoretical model was elaborated and analyzed by structural equation modeling.

Structural equation modeling proposes three main analyzes: the confirmatory factorial analysis (CFA); the evaluation of the measurement model; and the evaluation of the structural model. In general, the measurement model evaluation allows to compare the measurements provided between indicators and constructs (measurement models), and between constructs (structural model) and, consequently, determine how well the theory fits the collected data. As this study contains only reflective constructs, the following measures were used: a) reliability indicator; b) composite reliability; c) convergent validity; and d) discriminant validity.

Regarding to CFA, at least one indicator of each construct was removed, with the exception of the "concerns about waste" construct. The evaluation of the reflective measurement model, on the other hand, proves the validation of all indicators used in the model. Finally, the evaluation of the structural model points to considerable explanatory power for endogenous constructs. Thus, regarding the results of the study, it was demonstrated that the mobilizing attitudes concerning the environment and precautions taken in the domestic environment influence positively a more engaged consumption, which presented a coefficient of determination $\left(\mathrm{r}^{2}\right)$ of $41.4 \%$, result that is supported by Mondini et al. (2018). It is noteworthy that the influence of mobilizing attitudes on engaged consumption is greater than the influence of precautions in the domestic environment.

These results are compatible with other studies that indicate that this activist posture and concerns in the domestic environment have abundant importance in the concretization of an engaged consumer (Barbosa \& Veloso, 2014; Gonçalves-Dias et al., 2009; Pato, Ros, \& Tamayo, 2005; Sousa \& Romero, 2018).

However, it has not yet been proven that the concern with waste influences positively on this kind of consumption. This result is contrary to the theoretical assertions raised, indicating that the role of the individual in recycling and reuse programs, for example, does not make him/her more engaged and, therefore, does not lead to the intention of consuming organic products. A possible explanation for the denial of this hypothesis would be the fact that the correct waste management actions are relatively new in Brazilian context (Barbosa \& Veloso, 2014), in which it is suggested a greater governmental attention for the people awareness and consequent reach of sustainable consumption habits.

As for the construct intention of consuming organic products, it presented a coefficient of determination $\left(\mathrm{r}^{2}\right)$ of $11.4 \%$, considered average. Considering that the only construct used in the model to explain the intention of consuming organic products was engaged consumption, this result is important as it confirms that a more engaged consumer has a greater intention of consuming organic products. Similarly, to the research by Hoffmann and Schlicht (2013), the results indicate that consumers are motivated by selfish attitudes to consume organic products instead of altruistic attitudes aimed at environmental preservation. Therefore, in the authors' view, the way in which the individual is motivated has a great impact on his/her consuming behavior and attitudes. Thus, not only the environmental dimensions have an influence on the intention of consuming these products, but also other stimuli such as market-related, psychological, and cultural, which impact the purchase decision. The results also confirm that the consumer seeks, in the consumption of organic food, a better quality of life, food security, and better flavor (Burnier, Guerra, \& Spers, 2018; Rodrigues et al., 2009; Yin et al., 2020). 


\section{Final Remarks}

The research achieved its goal of proposing and testing a theoretical model to evaluate how some dimensions of environmental awareness influence consumer engagement and how this engagement influences the intention of consuming organic products. We presented and validated a model consistent with the literature and with high explanatory value concerning engaged consumption and mean explanatory value for the construct intention of consuming organic products.

The study was able to fill a gap in the studies of the area, extending discussions that demonstrate the relationship between individuals and nature, moderated by criteria for more sustainable food choices, expressing society's requirement regarding the modern food offer. The model presented and validated proved that the increased environmental awareness of citizens leads to a higher consumption of organic products (Sarkis, Zhu, \& Lai, 2011), highlighting some relations between the environmental and social dimensions and the motivations for consumption of organic food, which still needed to be better explored (Dias et al., 2015; Toni et al., 2018). In addition, the study validated a scale for some dimensions of environmental awareness and intention of consuming organic products in the Brazilian context, fact that, when added to the model validation, can be considered the greatest study academic contribution.

Despite the zeal and methodological rigor, the sample size used here can be identified as limiting the conclusions generalization. However, the results can, even if in a simple way, offer contributions. Regarding to managerial collaboration, this research provides a basis for the projection of strategies to retailers of organic food, which must find out who are the consumers of this class of foods and, therefore, draw loyalty plans, as well as observe the obstacles preventing the consumption of these foods. Thus, the study can generate insights for professionals and consumers to understand more systematically the buying behavior in this market.

A sample of university students was used. In agreement with Sousa and Romero (2018), these students, in addition to consumers, will be the future workers responsible for employing cleaner technologies in the production processes. However, the use of university students as a sample from only one Brazilian public higher education institution represents another limitation of the study. Thus, it is suggested that future research seeks to understand at other institutions and at other levels of education, such as postgraduate, master's and doctoral degrees, whether greater environmental awareness influences a greater intention to purchase organic products.

As other limitations of the research, we can highlight: the non-probabilistic nature and convenience of the sample used, which do not allow a generalization of the results; the choice of some dimensions of environmental awareness, which may not include all the points needed for the analysis of engaged consumption and intention of consuming organic products; and the cross-sectional nature for data collection, which hinders an analysis to understand how the association between variables of interest happens over time.

Therefore, we have the others following suggestions for future research: inclusion of other dimensions of environmental awareness to the model, especially those involving market-related, technological, psychological, economic, social, and cultural stimuli, among others, to understand what comes prior to the intention of consuming organic products; longitudinal research involving the relationship between the presented variables; cross-sectional studies with other agents involved in the chain, such as producers, traders, and researchers; qualitative studies that can offer an in-depth perspective of the results; and exploration of the conscious waste management field for a greater environmental awareness.

Finally, although the proposition that the concern with waste management directly impacts on more engaged consumption has been denied, this study concludes that the individual's mobilization on environmental issues and the attention given to the domestic environment positively influence engaged 
consumption, proving that this involvement has a positive relationship with the consuming organic products intention.

\section{References}

Aprile, M.C., Fiorillo, D. (2019). Intrinsic incentives in household waste recycling: the case of italy in the year 1998: The case of Italy in the year 1998. Journal of Cleaner Production, 227, 98-110. Elsevier BV. http://dx.doi.org/10.1016/j.jclepro.2019.04.184.

Barbosa, L., \& Veloso, L. (2014). Consumption, domestic life and sustainability in Brazil. Journal of Cleaner Production, 63, 166-172. Elsevier BV. http://dx.doi.org/10.1016/j.jclepro.2013.09.020.

Barcellos, M.D., Bossle, M.B., Perin, M.G., \& Vieira, L.M. (2015). Consumption of eco-innovative food: how values and attitudes drive consumers' purchase of organics? Revista brasileira de marketing, 14(1), 110121, University Nove de Julho.

Bauman, Z. (2008). Vida para o consumo: a transformação das pessoas em mercadorias. Rio de Janeiro: Jorge Zahar Editor.

Brady, M.K., \& Cronin, J.J. (2001). Some New Thoughts on Conceptualizing Perceived Service Quality: A Hierarchical Approach. Journal of Marketing, 65 (3), 34-49.

Burnier, P.C., Guerra, D.S., \& Spers, E.E. (2018). Attitudes and the Influence of Environmental Attributes on the Intention of Buying Beef. EnANPAD 2018, Curitiba, 1-17.

Campos, A.C., Hidalgo, G., Kist, J.I., Pedroso, J.P., \& Dalmoro, M. (2018). Empreendedorismo Institucional em prol da Sustentabilidade: a Dimensão Escondida nos Estudos acerca da Produção de Alimentos Orgânicos. EnANPAD 2018, Curitiba, p. 1-17, out.

Chiaretti, P., \& Sarti, M.M. (2017). O "destino do homem" no discurso sobre a ecologia e o consumo consciente. Fórum linguístico, Florianópolis, 14(2), 2128-20138, Universidade Federal de Santa Catarina (UFSC).

Chin, W.W., \& Newsted, P.R. (1999). Structural equation modeling analysis with small samples using partial least squares. Statistical strategies for small sample research, 1, 307-341.

Cohen, J. (1988). Statistical power analysis for the behavioral sciences. $2^{\mathrm{a}}$ ed. Hillsdale, NJ: Erlbaum, 1988.

Dalmoro, M. (2018). Dimensões da Construção de Mercados: um Olhar Integrado na Produção e no Consumo de Alimentos Orgânicos. EnANPAD 2018, Curitiba, 1-17.

Dias, V.V., Schultz, G., Schuster, M.S., Talamini, E., \& Révillion, J.P. (2015). O Mercado De Alimentos Orgânicos: Um panorama quantitativo e qualitativo das publicações internacionais. Ambiente \& Sociedade, 8(1), 161-182.

Gonçalves-Dias, S.L.F., Teodósio, A.S.S., Carvalho, S., \& Silva, H.M.R. (2009). Consciência ambiental: um estudo exploratório sobre suas implicações para o ensino de administração. $\boldsymbol{R A} \boldsymbol{E}$ eletrônica, São Paulo, 8(1), 1-23.

Green America (2013). The big green opportunity for small business in the U.S.: Small business sustainability report. Washington, DC: Russ Gaskin, Martha Van Gelder. Retrieved from http://biggreenopportunity.org/wp-content/uploads/2013/05/Big-Green-Opportunity-Report-

FINAL-WEB.pdf

Efron, B., \& Tibshirani, R.J. (1998). An introduction to the bootstrap. Chapman \& Hall / CRC Press, 1998.

Faul, F., Erdfelder, E., Buchner, A., \& Lang, A.G. (2009). Statistical power analyses using G* Power 3.1: Tests for correlation and regression analyses. Behavior research methods, 41, 149-1160.

Fornell, C., \& Larcker, D.F. (1981). Evaluating structural equation models with unobservable variables and measurement error. Journal of Marketing Research, 18, 39-50. 
Hair, J.F., Black, W.C., Babin, B.J., Anderson, R.E., \& Tatham, R.L. (2009). Análise Multivariada de Dados. $6^{a}$ ed. Porto Alegre: Bookman, 2009.

Hair, J.F., Hult, G.T.M., Ringle, C.M., \& Sarstedt, M. (2017). A Primer on Partial Least Squares Structural Equation Modeling (PLS-SEM). $2^{\mathrm{a}}$ ed. Thousand Oaks: SAGE, 2017.

Hair, J.F., Ringle, C.M., \& Sarstedt, M. (2011). PLS-SEM: Indeed a Silver Bullet. Journal of Marketing Theory and Practice, 19, pp. 139-151.

Hoffmann, S., \& Schlicht, J. (2013). The impact of different types of concernment on the consumption of organic food. International journal of consumer studies, Kiel, 37(6), 625-633.

Hoppe, A., Barcellos, M.D., Vieira, L.M., \& Matos, C.A. (2012). Comportamento do consumidor de produtos orgânicos: uma aplicação da teoria do comportamento planejado. BASE - Revista de administração e contabilidade da Unisinos, 9(2), 174-188. UNISINOS - Universidade do Vale do Rio Dos Sinos.

Hsu, S.Y., Chang, C., \& Lin, T.T. (2018). Triple bottom line model and food safety in organic food and conventional food in affecting perceived value and purchase intentions. British food journal, 1-14.

IFOAM. (2014). Definition of organic agriculture.

Jacomossi, R.R., Morano, R., \& Barrichello, A. (2014). O comportamento ambiental de estudantes de graduação: um modelo internacional de equações estruturais aplicado no contexto brasileiro. Revista de gestão social e ambiental, São Paulo, 8(3), 106-117.

Kim, Y. (2018). Organic shoppers' involvement in organic foods: self and identity. British food journal, $1-18$.

Lima, P.H.G., Ferreira, T.C., Bezerra, Y.M.S., Feitosa, M.J.S., \& Gómez, C.R.P. (2016). Consumo consciente: um estudo com estudantes do curso de administração da universidade federal rural de Pernambuco, unidade acadêmica de serra talhada. Revista de administração, contabilidade e economia da FUNDACE, Serra Talhada, 6(2), 98-108. FUNDACE.

Lombardi, M.S., Moori, R.G., \& Sato, G.S. (2005). Um estudo exploratório dos fatores relevantes na decisão de compra de produtos orgânicos. Revista de administração Mackenzie, São Paulo, 1, 13-34.

Macêdo, K.B., \& Oliveira, A. (2005). A gestão ambiental nas organizações como nova variável estratégica. Revista Psicologia: organizações e trabalho. 5(1), 129-158.

Melo, E.C., \& Brunstein, J. (2014). Experiências docentes de educação para sustentabilidade na sala de aula de administração. Pretexto, Belo Horizonte, 15, 116-135.

Minehira, C. (2010). Luta por direitos civis levou o consumo consciente para agenda mundial: 15 de outubro foi instituído Dia do Consumidor Consciente no Brasil; conheça a trajetória do tema no exterior e como chegou e ganhou força aqui. Instituto Akatu.

Mondini, V.E.D., Borges, G.R., Mondini, L.C., \& Dreher, M.T. (2018). Influência dos fatores consciência ambiental e hábitos de consumo sustentável sobre a intenção de compra de produtos ecológicos dos indivíduos. Revista Pensamento Contemporâneo em Administração, 12(2), 117-129. Departamento de Empreendedorismo e Gestão da UFF. http://dx.doi.org/10.12712/rpca.v12i2.1178.

Nunally, J.C., \& Bernstein, I. (1994). Psychometric theory. New York: McGraw-Hill, 1994.

Ormond, J.G.P., Paula, S.R.L., Faveret Filho, P.S.C., \& Rocha, L.T.M. (2002). Agricultura orgânica: quando o passado é futuro. BNDES setorial, Rio de Janeiro, 15, 3-34.

Pato, C. (2004). Comportamento ecológico: relação com valores pessoais e crenças ambientais. Tese de Doutoramento em Psicologia. Universidade de Brasília, Brasília: UnB. 
Pato, C., Ros, M., \& Tamayo, Á. (2005). Creencias y comportamiento ecológico: un estudio empírico con estudiantes brasileños. Medio ambiente y comportamiento humano, Madrid, 6, 5-22.

Pinheiro, L.V.S., Carneiro, C.M.F.M.L., Pinheiro, J.Q., \& Nascimento, J.C.H.B. (2018). De saberes e sabores à escolha alimentar: uma análise a partir da conectividade com a natureza e da orientação temporal para o consumo de alimentos orgânicos. Revista de gestão social e ambiental, São Paulo, 2(12).

Pinto, M.R., \& Batinga, G.L. (2016). O consumo consciente no contexto do consumismo moderno: algumas reflexões. Revista gestão.org. 14, 30-43.

Portilho, F. (2008). Consumidores de alimentos orgânicos: discursos, práticas e auto-atribuição de responsabilidade socioambiental. $26^{a}$ reunião brasileira de antropologia, Porto Seguro.

Ringle, C.M., Wende, S., \& Becker, J. (2015). SmartPLS 3. Bönningstedt: SmartPLS, 2015.

Rodrigues, R.R., Carlos, C.C., Mendonça, P.S.M., \& Correa, S.R.A. (2009). Atitudes e fatores que influenciam o consumo de produtos orgânicos no varejo. Revista brasileira de marketing, São Paulo, 8, 164-186.

Rotta, M., Batistela, A.C., \& Ferreira, S.R. (2017). Ambientalização curricular no ensino superior: formação e sustentabilidade nos cursos de graduação. Actualidades investigativas en educación, Costa Rica, 17(2), 1-21. Universidad de Costa Rica.

Sarkis, J., Zhu, Q., \& Lai, K.H. (2011). An organizational theoretic review of green supply chain management literature. International Journal of Production Economics, 130(1), 1-15. doi:10.1016/j.ijpe.2010.11.010

Straughan, R.D., \& Roberts, J.A. (1999). Environmental segmentation alternatives: A look at green consumer behavior in the new millennium, Journal of Consumer Marketing, 16(6), 558-575.

Sousa, E.S., \& Romero, C.B.A. (2018). Valores materiais e de consumo ecológico: Quais influenciam a intenção de compra? Revista Pensamento Contemporâneo em Administração, 12(3), Departamento de Empreendedorismo e Gestão da UFF. http://dx.doi.org/10.12712/rpca.v12i3.13214.

Telocken, S.G., Garlet, V., Favarin, R., Madruga, L.R., \& Trevisan, M. et al. O consumo consciente entre os alunos de administração de uma universidade federal brasileira sob a ótica da educação para a sustentabilidade. Revista gestão e desenvolvimento, Novo Hamburgo, 14(1), 100-113.

Toni, D.D., Eberle, L., Larentis, F., \& Milan, G.S. (2018). Antecedents of perceived value and repurchase intention of organic food, Journal of Food Products Marketing, 24(4), 456-475, DOI: 10.1080/10454446.2017.1314231

Yin, J., Yang, D., Zhang, X., Zhang, Y., Cai, T., Hao, Y., Cui, S., \& Chen, Y. (2020). Diet shift: considering environment, health and food culture: Considering environment, health and food culture. Science of The Total Environment, 719, 1-12. Elsevier BV. http://dx.doi.org/10.1016/j.scitotenv.2020.137484. 